Assiut University web-site: www.aun.edu.eg

\title{
ENTEROTOXIGENIC STAPHYLOCOCCUS AUREUS IN RAW AND PASTEURIZED MILK AND SOME MILK PRODUCTS
}

\author{
SANYA, T. EL-GHAMRY and EL-DOSOKY H.F.A \\ Food Hygiene Dept. Mansoura Provential Lab., Animal Health Research Institute, Egypt
}

Received: 31 March 2018; Accepted: 29 April 2018

\begin{abstract}
This study was carried out on 250 samples of milk and milk products (50 samples each of raw milk, pasteurized milk, soft white cheese, butter and ice cream). The samples were collected from different shops at Mansoura city, El Dakahlia Province, Egypt and bacteriologically analyzed to detect the prevalence of Staph. aureus and its enterotoxins using PCR and SET-RPLA kits. The results revealed that the incidence of Staph. aureus were 36, 4, 24,8 and $4 \%$ with mean counts of $3.8 \pm 1.4,1.78 \pm 0.48,3.4 \pm 1.25,2.39 \pm 0.95$ and $2.14 \pm 0.78 \log _{10} \mathrm{cfu} / \mathrm{g}$ or $\mathrm{ml}$ respectively. The examined positive Staph. aureus by PCR and SET-RPLA kits showed presence of the following enterotoxigenic genes in the examined raw market milk; white soft cheese and table butter samples (sea, seb and see); (sea, sed and see) and (sea and seb) respectively. Meanwhile, the enterotoxigenic genes could not be detected in the examined pasteurized milk and small scale ice cream samples thus, it is necessary to adopt a regime of good, safe and healthy production of such products with periodical cleaning and disinfection to ensure safe products for consumer.
\end{abstract}

Key words: Enterotoxiginic, Stath. aureus, milk, milk products.

\section{INTRODUCTION}

Milk and Milk products are highly nutritious products specially for young and old aged due to its contents of proteins, fats, sugars, minerals and vitamins hence, they may exposed to be contaminated with bacteria through animals or its contact environment or handling and distribution. Staph. aureus was one of the dominant bacteria associated with raw milk. This might be due to the fact that milk is a good nutritive medium for microorganisms growth especially in poor sanitary conditions and lack of cooling facilities. Sattar et al. (2001) and Mubarack et al. (2010) added that Staph. aureus introduced into the milk also by droplet infection or from udder surface and milker's hands.

Normanno et al. (2005); Bhatia and Zahoor (2007) and Rabello et al. (2007) mentioned that Staph. aureus commonly causes gastroenteritis resulting from consumption of contaminated food in which enterotoxigenic staphylococci have grown and

Corresponding author: Dr. EL-DOSOKY H.F.A

E-mail address: rafat552008@yahoo.com

Present address: Food Hygiene Dept. Mansoura Provential Lab, Animal Health Research Institute, Egypt produced toxins. As these toxins are excreted from the organism, they are referred to as exotoxins. Staphylococcal enterotoxins are considered a potential biological threat because of their stability at $100^{\circ} \mathrm{C}$ for 1 hour.

Zhang et al. (1998); Atanassova et al. (2001); Loir et al. (2003) and Alegro et al. (2007) assured that Staphylococcal enterotoxicosis has a very rapid onset and course characterized by vomiting, headache, abdominal pain, and diarrhea develop as early as one to six hours after consumption of contaminated food. The symptoms resolve spontaneously within 24-48 hours. Meanwhile, Lina et al. (2004) added that Staph. aureus enterotoxicosis are due to the classical enterotoxins (SEA, SEB, SEC, SED, SEE) and several new variants of SEs.

Bergdoll (1983) and Letertre et al. (2003) concluded that the first five (A to E) classical enterotoxins are known to cause $95 \%$ of the food poisoning globally and Argudin et al. (2010) isolate 22 types of SEs designated with letters A-V are currently known. While, Bennett, (2005) demonstrated that there is a strong association between the ability of Staph. aureus strains to produce one or more of the SEs and the occurrence of staphylococcal food poisoning. Weronika and Jacek (2014) found that $11.9 \%$ of the 
isolated strains were positive for one or more classical SE markers. The aim of this study was to detect enterotoxigenic Staph. aureus prevalence which is a potential source of food poisoning

\section{MATERIALS AND METHODS}

Two hundred and fifty samples of milk and milk products (50 samples each) of raw market milk, pasteurized milk, soft white cheese, table butter and small scale ice cream were collected from different shops at Mansoura city and sent to the laboratory in icebox for examination without delay.

Enumeration and Isolation of Coagulase positive Staph. aureus according to (APHA 2001) $10 \mathrm{ml}$ or $\mathrm{g}$ each of examined milk and milk product samples were taken aseptically and homogenized with $90 \mathrm{ml}$ $0.1 \%$ peptone water in a stomacher for 3 minutes at $3000 \mathrm{rpm}$ and filtered through a sterile cheese cloth filter, followed by six fold serial dilutions in $0.1 \%$ peptone water then $0.1 \mathrm{ml}$ were taken from each dilution aseptically and inoculated onto Baird-Parker medium, the plates were incubated for 24-48 hours at $37^{\circ} \mathrm{C}$. The plates containing 20-200 colonies were selected. Typical colonies of Staph. aureus were circular, smooth, convex, moist $2-3 \mathrm{~mm}$ in diameter, grey to black (potassium tellurite reaction) with white margin and surrounded by outer clear zone (egg yolk reaction) the suspected colonies were streaked onto agar slant of nutrient agar medium and incubated at $37^{\circ} \mathrm{C}$ for 24 hours for further purification and identification by microscopical and biochemical examination by catalase, coagulase, thermostable nuclease and Voges-Proskauer tests.

Staph. aureus culture supernatant were collected by Sac cultural method (Donnelly et al., 1967) and tested serologically by reversed passive latex agglutination technique using Oxoid SET-RPLA kits for the presence of SEA, SEB, SEC, SED and SEE.

Extraction of Staph. aureus enterotoxins from the examined samples were completed by blending of 10 ml of milk or milk product samples with $10 \mathrm{ml}$ of sodium chloride solution $(0.85 \%)$ and centrifuged.
The supernatant was retained for toxin detection using Oxoid SET-RPLA kits Shingaki et al. (1981).

Detection of virulence genes in Staph. aureus using PCR (Reference Lab for Quality Control on Poultry Production, Animal Health Research Institute, Dokki -Egypt)

\section{1-DNA extraction:}

DNA extraction from samples was performed using the QIAamp DNA Mini kit (Qiagen, Germany, $\mathrm{GmbH}$ ) with modifications from the manufacturer's recommendations. Briefly, $200 \mu \mathrm{l}$ of the sample suspension was incubated with $10 \mu$ l of proteinase $\mathrm{K}$ and $200 \mu \mathrm{l}$ of lysis buffer at $56^{\circ} \mathrm{C}$ for $10 \mathrm{~min}$. After incubation, $200 \mu 1$ of $100 \%$ ethanol was added to the lysate. The sample was then washed and centrifuged following the manufacturer's recommendations. Nucleic acid was eluted with $100 \mu 1$ of elution buffer provided in the kit.

2- Oligonucleotide Primer. Primers used were supplied from Metabion (Germany) are listed in Table (1).

3- For multiplex PCR of enterotoxins, Primers were utilized in a $50-\mu 1$ reaction containing $25 \mu 1$ of Emerald Amp Max PCR Master Mix (Takara, Japan), $1 \mu \mathrm{l}$ of each primer of $20 \mathrm{pmol}$ concentration, $8 \mu \mathrm{l}$ of water, and $7 \mu \mathrm{l}$ of DNA template. The reaction was performed in an Applied biosystem 2720 thermal cycler.

\section{4- Analysis of the PCR Products.}

The products of PCR were separated by electrophoresis on $1.5 \%$ agarose gel (Applichem, Germany, GmbH) in 1xTBE buffer at room temperature using gradients of $5 \mathrm{~V} / \mathrm{cm}$. For gel analysis, $30 \mu \mathrm{l}$ of the multiplex PCR products were loaded in each gel slot. Gelpilot 100 bp DNA ladder (Qiagen, Germany, $\mathrm{GmbH}$ ) was used to determine the fragment sizes. The gel was photographed by a gel documentation system (Alpha Innotech, Biometra) and the data was analyzed through computer software. 
Table 1: Primers sequences, target genes, amplicon sizes and cycling conditions of Staphylococcus aureus enterotoxins.

\begin{tabular}{|c|c|c|c|c|c|c|c|c|}
\hline \multirow{2}{*}{$\begin{array}{l}\text { Target } \\
\text { gene }\end{array}$} & \multirow[t]{2}{*}{ Primers sequences } & \multirow{2}{*}{$\begin{array}{c}\text { Amplified } \\
\text { segment } \\
\text { (bp) }\end{array}$} & \multirow{2}{*}{$\begin{array}{c}\text { Primary } \\
\text { denaturation }\end{array}$} & \multicolumn{3}{|c|}{ Amplification ( 35 cycles) } & \multirow{2}{*}{$\begin{array}{c}\text { Final } \\
\text { extension }\end{array}$} & \multirow[t]{2}{*}{ Reference } \\
\hline & & & & $\begin{array}{c}\text { Secondary } \\
\text { denaturation }\end{array}$ & Annealing & Extension & & \\
\hline \multirow[t]{3}{*}{ Sea } & GGTTATCAATGTG & 102 & $94^{\circ} \mathrm{C}$ & $94^{\circ} \mathrm{C}$ & $50^{\circ} \mathrm{C}$ & $72^{\circ} \mathrm{C}$ & $72^{\circ} \mathrm{C}$ & Mehrotra \\
\hline & CGGGTGG & & $5 \mathrm{~min}$. & $30 \mathrm{sec}$. & $40 \mathrm{sec}$. & $40 \mathrm{sec}$. & $10 \mathrm{~min}$. & et al. 2000 \\
\hline & $\begin{array}{c}\text { CGGCACTTTTTTC } \\
\text { TCTTCGG }\end{array}$ & & & & & & & \\
\hline \multirow[t]{4}{*}{ Seb } & GTATGGTGGTGT & 164 & & & & & & \\
\hline & AACTGAGC & & & & & & & \\
\hline & CCAAATAGTGAC & & & & & & & \\
\hline & GAGTTAGG & & & & & & & \\
\hline \multirow[t]{4}{*}{ Sec } & AGATGAAGTAGT & 451 & & & & & & \\
\hline & TGATGTGTATGG & & & & & & & \\
\hline & CACACTTTTAGAA & & & & & & & \\
\hline & TCAACCG & & & & & & & \\
\hline \multirow[t]{4}{*}{ Sed } & CCAATAATAGGA & 278 & & & & & & \\
\hline & GAAAATAAAAG & & & & & & & \\
\hline & ATTGGTATTTTTT & & & & & & & \\
\hline & TTCGTTC & & & & & & & \\
\hline \multirow[t]{4}{*}{ See } & AGGTTTTTTCACA & 209 & & & & & & \\
\hline & GGTCATCC & & & & & & & \\
\hline & СТTTTTTTTCTTC & & & & & & & \\
\hline & GGTCAATC & & & & & & & \\
\hline
\end{tabular}

\section{Statistical analysis:}

The results are expressed as $\log$ mean \pm standard error (SE). Data were statistically analyzed using statistical analysis systems.

\section{RESULTS}

Table 2: Mean counts of Staph. aureus in the examined samples expressed as $\log _{10} \mathrm{cfu} / \mathrm{g}$ or $\mathrm{ml}(\mathrm{n}=50)$.

\begin{tabular}{lccccc}
\hline Examined products & Raw milk & $\begin{array}{c}\text { Pasteurized } \\
\text { milk }\end{array}$ & $\begin{array}{c}\text { White soft } \\
\text { cheese }\end{array}$ & Butter & Ice cream \\
\hline Mean counts of Staph. aureus & $3.8 \pm 1.4$ & $1.78 \pm 0.48$ & $3.4 \pm 1.25$ & $2.39 \pm 0.95$ & $2.14 \pm 0.78$ \\
\hline
\end{tabular}

$\mathrm{NB}: \mathrm{n}=$ number of the examined samples

Table 3: Incidence and Disribution of enterotoxins produced by Staph. aureus strains isolated from the examined samples by SET-RPLA kits and PCR $(n=50)$.

\begin{tabular}{|c|c|c|c|c|c|c|c|c|c|}
\hline \multirow{2}{*}{ Examined products } & \multicolumn{2}{|c|}{$\begin{array}{l}\text { No and incidence } \% \text { of } \\
\text { the isolated strains }\end{array}$} & \multicolumn{2}{|c|}{$\begin{array}{c}\text { No of strains } \\
\text { Producing enterotoxins }\end{array}$} & \multicolumn{5}{|c|}{$\begin{array}{l}\text { Types of produced } \\
\text { enterotoxins }\end{array}$} \\
\hline & $\mathrm{No} / 50$ & $\%$ & No & $\begin{array}{c}\text { Frequency } \\
\%\end{array}$ & A & $\mathrm{B}$ & $\mathrm{C}$ & $\mathrm{D}$ & $\mathrm{E}$ \\
\hline Raw market milk & 18 & 36 & 3 & 16.66 & SEA & SEB & & & SEE \\
\hline Pasteurized milk & 2 & 4 & - & - & - & - & - & - & - \\
\hline white soft cheese & 12 & 24 & 3 & 25 & SEA & - & - & SED & SEE \\
\hline Butter & 4 & 8 & 2 & 50 & SEA & SEB & - & - & - \\
\hline Ice cream & 2 & 4 & - & - & - & - & - & - & - \\
\hline
\end{tabular}


Results of Polymerase chain reaction:

Multiplex PCR for enterotoxiginic Staph. aureus genes:
Results of the isolated Staph. aureus from the examined raw milk by using multiplex PCR using sets of primers for enterotoxins (A,B,C,D and E) showed that

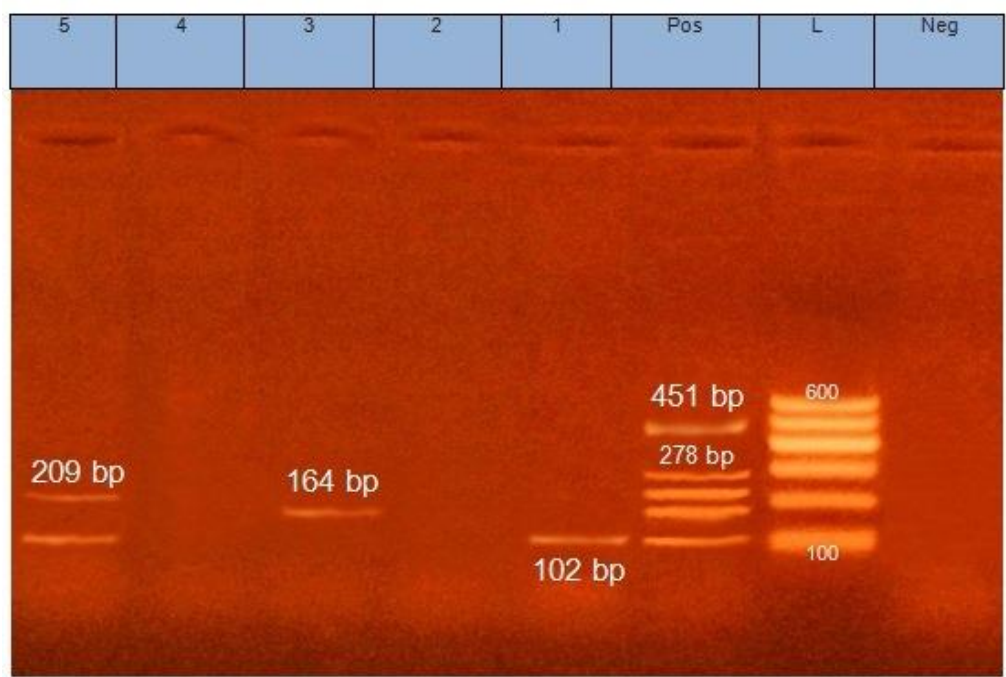

Fig (1): Agarose gel electrophoresis of Staph. aureus PCR products using enterotoxins Staph. aureus primer Pos=positive control, Neg=negative control, L=100 bp DNA ladder

Lane "1": positive amplification of 102 bp for enterotoxin A

Lane " 2 "and Lane " 4 " were negative

Lane "3": positive amplification of $164 \mathrm{bp}$ for enterotoxin B

Lane "5": positive amplification of 102 bp for enterotoxin A, 209 bp for enterotoxin E

Results of the isolated Staph. aureus from examined white soft cheese samples (Lane 1,2\&3) and butter samples (Lane $4 \& 5$ ) by using multiplex PCR using sets of primers producing enterotoxins (A,B,C,D and E) showed that

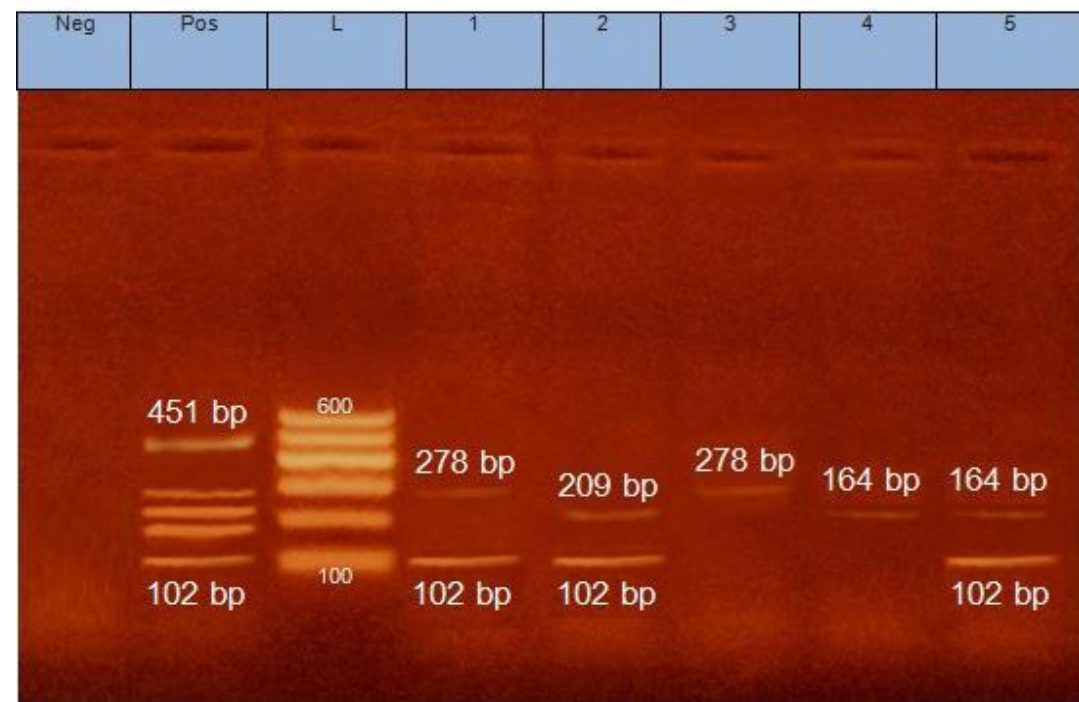

Fig (2): Agarose gel electrophoresis of Staph. aureus PCR products using enterotoxins Staph. aureus primer Pos=positive control, $\mathrm{Neg}=$ negative control, $\mathrm{L}=100 \mathrm{bp}$ DNA ladder

Lane "1": positive amplification of 102 bp for enterotoxin A and 278 bp for enterotoxin D

Lane "2" positive amplification of $102 \mathrm{bp}$ for enterotoxin A and $209 \mathrm{bp}$ for enterotoxin E

Lane "3" positive amplification of 278 bp for enterotoxin D

Lane "4": positive amplification of 164 bp for enterotoxin B

Lane "5": positive amplification of 102 bp for enterotoxin A and164 bp for enterotoxin B 


\section{DISCUSSION}

Presence of lactic acid bacteria lowering the $\mathrm{pH}$ in raw milk that may prevent Staph. aureus growth and enterotoxin production (Alomar et al., 2008 and Janstova et al., 2012). Pinchuk et al. (2010) mentioned that bacterial counts of Staph. aureus need to reach $10^{5}-10^{8} \mathrm{cfu} / \mathrm{mL}$ before sufficient amount of toxin to cause illness is produced while, Evenson et al. (1988) showed that growth of enterotoxigenic Staph. aureus up to $10^{6}$ or more/g of food enables them to produce a sufficient amount of enterotoxins to cause intoxication. As little as 20ng of SE can induce nausea, violent vomiting, abdominal cramps, and diarrhea between 1 to $8 \mathrm{~h}$ after food consumption. The achieved results in Tables 2,3 and Fig. 1 declared that the highest contamination of Staph. aureus were found in raw market milk with mean counts of 3.8 $\pm 1.4 \log _{10} \mathrm{cfu} / \mathrm{ml}$ with incidence percent of $36 \%$ mean while, 3 out of the examined 18 isolates by PCR and SET-RPLA kits were enterotoxigenic. The enterotoxigenic strains have sea, seb and see virulent genes, these results were nearly in accordance with Manfreda et al. (2005) who found $34.6 \%$ of milk samples were contaminated with Staph. aureus, 6.6\% of which were enterotoxin producers. Enterotoxigenic strains were most frequently detected in milk with Staph. aureus count $4.47 \log _{10} \mathrm{cfu} / \mathrm{ml}$; Bianchi et al. (2013) declared that $53 \%$ of raw milk were positive for one or more SE genes and Staph. aureus count were $3.5 \pm 2.38 \log _{10} \mathrm{cfu} / \mathrm{ml}$ with incidence percent of $32 \%$. Also, Thabet et al. (2014) revealed that Staph. aureus was isolated with a percentage of $26.6 \%$ from raw milk; Hu Shou Kui et al. (2013) found Staph. aureus in $30.0 \%$ of examined raw milk and $43.7 \%$ of the isolated Staph. aureus produced enterotoxins. These results were lower than that reported by Weronika and Jacek (2014) and Gundogan and Avc (2014) who found the incidence percent in raw milk were 56\% and higher than Rajeev and Amit (2010) who could isolate Staphylococcus from milk by $10 \%$.

The obtained results of Staph. aureus count and its incidence in Pasteurized milk in Tables 2 and 3 declared that the mean counts were $1.78 \pm 0.48$ $\log _{10} \mathrm{cfu} / \mathrm{ml}$ with incidence percent of $4 \%$ mean while, the enterotoxigenic strains of Staph. aureus could not be detected by PCR and SET-RPLA kits. These results were in accordance with those obtained by Gad EL-Said et al. (2013) who reported that no enterotoxigenic Staph. aureus were detected in pasteurized milk and Asao et al. (2003) who added that pasteurizing raw milk would eliminate Staph. aureus from raw milk, however once the pathogens have produced enterotoxins the toxins will remain stable even after pasteurization. Also, Jicinska and Havlova (1995) concluded that because of its heat resistance, Staph. aureus can be detected even in pasteurized milk in addition to Anderson et al. (1996) shown that Staph. aureus enterotoxins are highly resistant to heat treatment, a good example is sea, which retained its biological activity even after exposure to $121^{\circ} \mathrm{C}$ for 28 minutes.

Jablonski and Bohach (2001) reported that $10^{3}$ and $10^{5} \mathrm{cfu} / \mathrm{g}$ Staph. aureus is able to produce enterotoxin in amounts that can pose a health risk to the consumers.

The achieved results of white soft cheese in Tables 2,3 and Fig 2 declared that the mean counts of Staph. aureus were $3.4 \pm 1.25 \log _{10} \mathrm{cfu} / \mathrm{g}$ with incidence percent $24 \%$ mean while, 3 out of the examined 12 isolates were enterotoxigenic detected in examined samples by PCR and SET-RPLA kits have the enterotoxigenic virulent genes sea, sed and see. These results were lower than Gundogan and Avc (2014) who found that $48 \%$ of white cheese were contaminated with Staph. aureus. While, Thabet et al. (2014) revealed that Staph. aureus was isolated with a percentage of $6.6 \%$ in Damietta cheese samples and $\mathrm{Hu}$ Shoukui et al. (2013) the positive rate of Staph. aureus in milk products including cheese were $7.5 \%$ and $43.7 \%$ of the isolated Staph. aureus produced enterotoxins. Gucukoglu et al. (2012) investigated that the enterotoxigenic Staph. aureus was detected in white cheese by $19 \%$, two isolates from cheese samples $50 \%$ were found to be enterotoxigenic. Rahimi (2013) reported that $11.1 \%$ of examined cheese were found to be contaminated with Staph. aureus and the ability to synthesize classical staphylococcal enterotoxins (SEA-E) was determined in 7 of $20(35 \%)$ isolates.

Bianchi et al. (2013) found that milk and dairy products account for $5 \%$ of all the incriminated foods poisoning.

Theresults of Staph. aureus incidence in Tables 2, 3 and Fig 2 of the examined table butter samples were $8 \%$ with mean count of $2.39 \pm 0.95 \log _{10} \mathrm{cfu} / \mathrm{g}$ and the enterotoxigenic virulent genes of Staph. aureus was detected in 2out of 4 isolates from the examined table butter samples. The isolated enterotoxigenic strains of Staph. aureus by PCR and SET-RPLA kits have sea and sebvirulent genes. These results were nearly in accordance with Rahimi, (2013) who found 5.3\% of butter samples contaminated with Staph. aureus and $35 \%$ of the isolated Staph. aureus were able to synthesize the classical staphylococcal enterotoxins (SEA-E). While, Gucukoglu et al. (2012) investigated that the enterotoxigenic Staph. aureus was detected in $30 \%$ of the examined butter samples and $25 \%$ of them showed enterotoxigenic character (SEB 100\%).

The results in Tables 2 and 3 indicated that the incidence percent of Staph. aureus in ice cream samples were $4 \%$, with mean counts $2.14 \pm 0.78$ $\log _{10} \mathrm{cfu} / \mathrm{ml}$. The enterotoxigenic strains could not be detected in the examined samples either by PCR or by 
SET-RPLA kits. Bostan and Akn (2002); Sagdc et al. (2003) and Hu ShouKui et al. (2013) could not found Staph. aureus in ice creams samples while, higher percentage were reported by Gunsen (2002) who found Staph. aureus in 5\% of lemon ice cream samples; Rahimi, (2013) found 5.9\% ice-cream contaminated with Staph. aureus and Gundogan and Avc (2014) found Staph. aureus in $36 \%$ of the examined ice cream samples. Nazem et al. (2010) isolate Staph. aureus from 5\% of ice cream collected from supermarkets; lower percentage were reported by Rajeev and Amit (2010) who isolated Staphylococcus from Ice cream by $1 \%$; Yucel and Ctak (2002) found Staph. aureus count $1.0 \times 10^{2}-$ $3.0 \times 10^{3} \mathrm{cfu} / \mathrm{ml}$ in ice cream samples. Guner et al. (2004) added that counts of Staph. aureus in ice cream were $1.2-1.7 \times 10^{3} \mathrm{cfu} / \mathrm{g}$ and El-Ansary (2015) found Staph. aureus count was $1.10 \times 10^{3} \pm$ $2.45 \times 10^{2} \mathrm{cfu} / \mathrm{ml}$ in Vanilla ice cream samples, which could be associated with potential food poisoning hazards. On the other side, Gucukoglu et al. (2012) investigated that the enterotoxigenic Staph. aureus was detected in $10 \%$ of ice cream samples.

Asao et al. (2003) mentioned that Staph. aureus were frequently contaminator for ice cream. Hence, improvement of the hygienic practice in processing, preparing and storage should be stressed and Schmitt et al. (1990) declared that the causes of staphylococcal enterotoxicosis are classical SEs. SEA, SEB, SEC1, SEC2, SEC3, SED, and SEE and the production of SEs is unlikely at temperatures below $10^{\circ} \mathrm{C}$.

Bergdoll (1989) concluded that a very small amount of Staph. aureus enterotoxins ranging from $20 \mathrm{ng}$ to < $1 \mu \mathrm{g}$ is needed to cause a typical symptoms of staphylococcal food poisoning. An outbreak in Japan caused by low-fat milk contaminated with SEA showed that the total intake of SEA per individual was estimated to be 20-100 ng, More recently, Ostyn et al. (2010) in France found an outbreak caused by contaminated cheese, doses of SEE ingested by symptomatic persons were estimated to be about 90 ng, based on the mean weight of the cheese portion (about $200 \mathrm{~g}$ ) and the total amount of SEE in food samples were $0.45 \mathrm{ng} / \mathrm{g}$.

\section{CONCLUSION}

The presence of enterotoxigenic Staph. aureus in raw milk and milk products poses a potential health hazard to the consumers. However, not only identification of such strains but also appropriate conditions for Staph. aureus enterotoxin genes during production and storage of milk and milk products should be taken into account in hazard risk analysis.

\section{REFERENCES}

Alomar, J.; Loubiere, P.; Delbes, C.; Nouaille, S. and Motel, M.C. (2008): Effect of Lactobacillus lactis and Enterococcus faecalis on the behaviour of Staph. aureus in microfiltered milk. Food Microbiol., 25: 502-508.

APHA (American Public Health Association) (2001): Compendium methods for the microbiological examination of food, Wahington, DC.

Alegro, A.L.C.; Konta, E.M. and Suzuki, K. (2007): Occurrence of coagulase positive Staphylococcus in various food products commercialized in Botucatu, SP, Brazil and detection of toxins from food and isolated strains. Food Control 18: 630-634.

Anderson, J.E.; Beelman, R.R. and Doores, S. (1996): Persistence of serological and biological activities of staphylococcal enterotoxin A in canned mushrooms. J. Food Protection 59: 1292-1299.

Argudin, M.A.; Mendoza, M.C.; Rodicio, M.R. (2010): Food Poisoning and Staph. aureus Enterotoxins. Toxins, 2: 1751-1773.

Asao T.; Kumeda, Y. and Kawai, T. (2003): An extensive outbreak of staphylococcal food poisoning due to low-fat milk in Japan estimation of enterotoxin A in the incriminated milk and powdered skim milk. Epidemiol Infect. 130: 33-40.

Atanassova, V.; Meindl, A. and Ring, C. (2001): Prevalence of Staph. aureus and staphylococcal enterotoxins in raw pork and uncooked smoked ham - a comparison of classical culturing detection and RFLP-PCR. Int. J. Food Microbiol, 68, 1-2: 105-113.

Bennett, R.W. (2005): Staphylococcal enterotoxin and its rapid identification in foods by enzymelinked immunosorbent assay-based methodology. J. Food Prot. 68: 1264-1270.

Bergdoll, M.S. (1989): Staph. aureus In Doyle MP. editor. Food-Borne Bacterial Pathogens. New York: Marcel Dekker. 464-523.

Bergdoll, M.S. (1983): Enterotoxins. In Easton CSF, Adlam C editors. Staphylococci and staphylococcal infections. London Academic Press. 559-598.

Bhatia, A. and Zahoor, S. (2007): Staph. aureus enterotoxins. J. Clin. Diag. Res., 1: 188-197.

Bianchi, D.M.; Gallina, S.; Bellio, A.; Chiesa, F.; Civera, T. and Decastelli, L. (2013): Enterotoxin gene profiles of Staph. aureus isolated from milk and dairy products in Italy. Letters in Applied Microbiology.58, 190-196.

Bostan, K. and Akn, B. (2002): A study on the microbiological quality of industrial icecream. Turk Veterinerlikve Hayvanclk Dergisi. 26(3): 623-629. 
Donnelly, C.B.; Leslie, J.E.; Black, L.A. and Lewis, K.H. (1967): Serological identification of enterotoxigenic Staph. aureus from cheese. Applied Microbiology. 15(6); 917-924.

El-Ansary, M.A. (2015): Hygienic quality of Vanilla ice cream sold at local market. Alexandria J. of Veterinary Sciences. 44:54-58.

Evenson, M.; Hinds, M.; Bernstein, R. and Bergdoll, M. (1988): Estimation of human dose of staphylococcal enterotoxin-A from a large outbreak of staphylococcal food poisoning involving chocolate milk. Int. J. Food Microbiol. 7, 311-316.

Gad EL-Said, W.A.; Morgan, S.D. Mona; ElShabrawy, Azza; Abuelnaga, S.M.; Elgabry, E.A. and Mansour, S.M. Asmaa (2013): Advanced Detection of Staph. aureus Enterotoxins in Milk. Glbal Veterinaria 11 (4): 403-405.

Gucukoglu, A.; Kevenk, T.O.; Uyanik, T.; Cadirci, O.; Terzi, G. and Alisarli, M. (2012): Detection of enterotoxigenic Staph. aureus in raw milk and dairy products by multiplex PCR. J. of Food Science. 77(11): M620-M623.

Gundogan, N. and Avc, E. (2014): Occurrence and antibiotic resistance of E. coli, Staph. aureus and Bacillus cereus in raw milk and dairy products in Turkey. International J. of Dairy Technology. 67(4): 562-569.

Guner, A.; Ardc, M. and Keles, A. (2004): Microbiological quality of ice creams sold at pastry shops in Konya. Veteriner Bilimleri Dergisi. 20(2): 59-64.

Gunsen, U. (2002): The hygienic qualities of ice creams consumed in the centre of Bursa. Pendik Veteriner Mikrobiyoloji Dergisi. 32(1/2): 31-36.

Hu Shou Kui; Liu Shi Yun; Hu Wan Fu; Zheng Tian $\mathrm{Li}$ and Xu Jian Guo (2013): Molecular biological characteristics of Staph. aureus isolated from food. European Food Research and Technology. 236(2): 285-291.

Jablonski, L.M. and Bohach, G. (2001): Staph. aureus In: DOYLE M. P., BEUCHAT, L. R., MONTVILLE, T. J. (ed): Food microbiology: Fundamentals and Frontiers. Washington: ASM Press, 411-434.

Janstova, B.J.R.; Necidova, L.; Janstova, B. and Vorlova, L. (2012): Staph. aureus growth and enterotoxin production in different types of milk. Actauniv. agric. etsilvic. Mendel. Brun., LX, No. 5; 103-108.

Jicinska, E. and Havlova, J. (1995): Patogennímikroorganismy $\mathrm{v}$ mléce a mléčnýchvýrobcích. 1. vyd Praha: ÚZPI, 106 s. ISBN 80-85120-47-X.

Letertre C.; Perelle S.; Dilasser, F. and Fach, P. (2003): Identification of a new putative enterotoxin SEU encoded by the egc cluster of Staph. aureus. J. Appl Microbiol 95: 38-43.
Lina, G.; Bohach, G.A.; Nair, S.P.; Hiramatsu, K.; Jouvin-Marche, E. and Maurizza, R. (2004): Standard nomenclature for the superantigens expressed by Staphylococcus. J. Infect Dis. 189, 2334-2336.

Loir, Y.; Baron, F. and Gautier, M. (2003): Staph. aureus and food poisoning. Genet Mol Res., 2, 1: 63-76.

Manfreda, G.; Mioni, R. and Cesare, A.De. (2005): Surveillance and characterization of enterotoxigenic staphylococci in foods of animal origin collected in the Veneto Region. Veterinary Research Communications; 29(Supp. 2): 331-333.

Mehrotra, M.; Wang, G. and Johnson, M.W. (2000): Multiplex PCR for detection of genes for Staph. aureus enterotoxin, exfoliative toxins, toxic shock syndrome toxin 1 , and Methicillin resistance. J. of Clinical Microbiology, Vol. 38: 1032-1035.

Mubarack, H.M.A.; Doss, R.; Dhanabalan and Balachander, S. (2010): Microbial quality of raw milk samples collected from different villages of Coimbatore District Tamilnadu South India. Indian J. of Science and Technology, 3 (1): 61-63.

Nazem, A.M.; Amer, A.A. and Soukayna, A.E. (2010): Prevalence of some food poisoning microorganisms in some dairy products. Alexandria J. of Veterinary Sciences. 30(1): $1-6$.

Normanno, G.; Firinu, A.; Virgilio, Mula, G.; Dambrosio, A.; Poggiu, O.; Decastelli, L.; Mioni, R.; Scuota, S.; Bolzoni, G.; Giannatale, E.; Salinetti, A.P.; Salandra, G.; Bartoli, M.; Zuccon, F.; Pirino, T.; Sias, S.; Parisi, A.; Quaglia, N.C. and Celano, G.V. (2005): Coagulase-positive staphylococci and Staph. aureus in food products marketed in Italy. Int, J. Food Microbiol, 98, 1;73-79.

Ostyn, A.; De Buyser, M.L.; Guillier, F.; Groult, J.; Felix, B; Salah, S.; Delmas, G. and Hennekinne, J.A. (2010): First evidence of a food poisoning outbreak due to staphylococcal enterotoxin type E, France, 2009. Euro Surveill 15.

Pinchuk, I.V.; Besvick, E.J. and Reyes, V.E. (2010): Staphylococcal enterotoxins.Toxins.2, 2; 177-219.

Rabello, R.F.; Moreira, B.M.; Lopes, R.M.M.; Teixeira, L.M.; Riley, L.W. and Castro, A.C.D (2007): Multilocus sequence typing of Staph. aureus recovered from cows with mastitis in Brazilian dairy herds. J. Med. Microbiol., 56, 11: 1505-1511.

Rahimi, E. (2013): Enterotoxigenicity of Staph. aureus isolated from traditional and commercial dairy products marketed in Iran. Brazilian J. of Microbiology. 44(2):393-399.

Rajeev, K. and Amit, P. (2010): Detection of E. coli and Staphylococcus in milk and milk products 
in and around Pantnagar. Veterinary World. 3(11): 495-496.

Sagdc, O.; Tuluoglu, D.D.; Ozcelik, S. and Simsek, B. (2003): The chemical and microbiological quality of ice cream consumed in Isparta marked. Ziraat Fakultesi Dergisi, Ataturk Universitesi. 33(4): 441-446.

Sattar, S.A.; Springthorpe, S.; Mani, Sgallant, M.; Nair, R.C.; Scott, E. and Kain, J. (2001): Transfer of bacteria from fabrics to hand and other fabrics: development and application of a quantitative method using Staph. aureus as a model. J. Appl Microbiol., 90, 6: 962-970.

Schmitt, M.; Schuler-Schmid, $U$. and SchmidtLorenz, W. (1990): Temperature limits of growth, TNase and enterotoxin production of Staph. aureus strains isolated from foods. Int. J. Food Microbiol., 11, 1: 1-19.

Shingaki, M.H.; Igarashi, H.; Fujikawa, H.; Ushiod, T.; Terayama and Sakai, S. (1981): Study on reversed passive latex agglutination for detection of staphylococcal enterotoxins A, B and C. Ann Rep. Tokyo Metrop. Res. Lab. Public Health. 32(1): 128-131.

Thabet, S.S.; Amin, M.M.; Elsherif, W.M.A.; Hasan, A.M.; Wahba, N.M. (2014): Phenotypic and genotypic methicillin resistant Staph. aureus (MRSA) isolated from raw milk and somedairy products. Global J. of Agriculture and Food Safety Sciences. 1:317-325.

Weronika Korpysa-Dzirb and Jacek Osek (2014): Detection of classical genes and enterotoxins of Staph. aureus isolated from raw milk in the south-east region of Poland. Bull Vet Inst Pulawy 58, 559-561.

Yucel, N. and Ctak, S. (2002): A study on existence of some microorganisms in ice-cream samples. Turk Hijyenve Deneysel Biyoloji Dergisi. 57(3): 165-169.

Zhang, S.P.; Iandolo, J.J. and Stewart, G.C. (1998): The enterotoxin D plasmid of Staph. aureus encodes a second enterotoxin determinant (sej). FEMS Microbiol Lett, 68, 2: 227-233.

\section{الميكروب العنقودى الذهبى المفرز للسموم فى اللبن الخام والمبستر وبعض منتجات الالبان \\ سنية طه الغدى ، حاتم فتحى احد اللسوقى \\ E-mail: rafat552008@yahoo.com Assiut University web-site: www.aun.edu.eg}

تعد الالبان ومنتجاتها من الأغذية الضرورية للإنسان فى جميع بلدان العالم لما تحتويه من عناصر غذائيه ضروريه لئه لبناء الجسم ولكنها

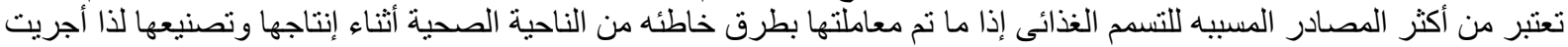

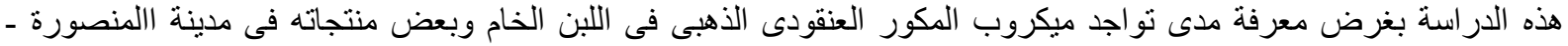

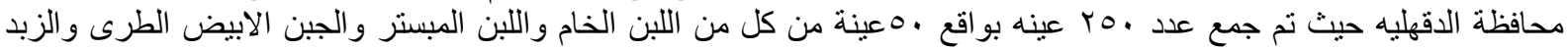

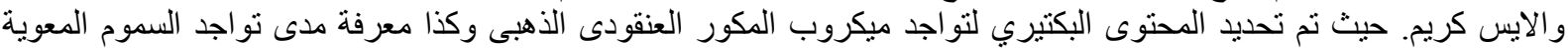

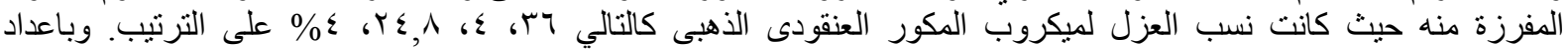
لی , ^

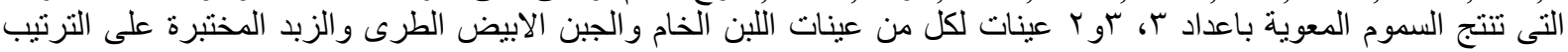

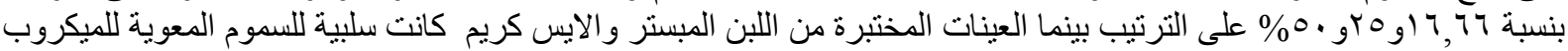

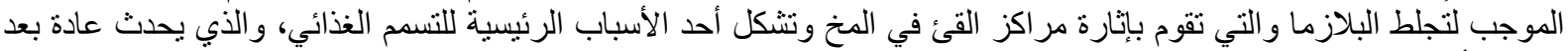

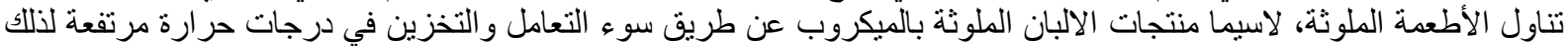

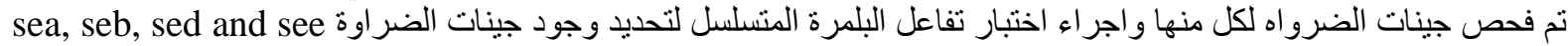

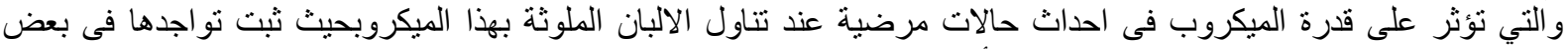

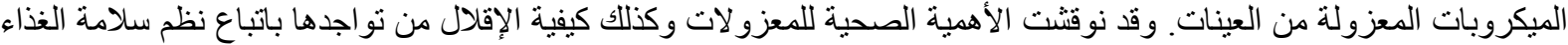

